\title{
Reflection of P53 Phenotype in Tumor Tissue by Genotypic Variants in Glutathione S-Transferases: An Association with DNA Damage in Lung Adenocarcinoma
}

Research Article

Keywords:

Posted Date: August 24th, 2021

DOI: https://doi.org/10.21203/rs.3.rs-450565/v2

License: (1) This work is licensed under a Creative Commons Attribution 4.0 International License. Read Full License 


\section{Abstract}

The full text of this preprint has been withdrawn by the authors as it was submitted and made public without the full consent of all the authors. Therefore, the authors do not wish this work to be cited as a reference. Questions should be directed to the corresponding author.

\section{Full Text}

The authors have withdrawn this preprint from Research Square. 